\section{Neonatal near miss and mortality: factors associated with life-threatening conditions in newborns at six public maternity hospitals in Southeast Brazil}

\author{
Casos de near miss e óbitos neonatais: fatores \\ associados aos recém-nascidos com ameaça à \\ vida em seis maternidades do Sudeste do Brasil
}

Morbilidad near miss y mortalidad neonatal: factores asociados a condiciones involucrando riesgo de muerte en recién-nacidos en seis maternidades del Sureste do Brasil

\begin{abstract}
We aimed to evaluate factors associated with cases of neonatal near miss and neonatal deaths at six public maternity hospitals in São Paulo and Rio de Janeiro States, Brazil, in 2011. A prospective hospital-based birth cohort investigated these outcomes among live births with life-threatening conditions. Associations were tested using multinomial logistic regression models with hierarchical levels. High rates of near miss were observed for maternal syphilis (52.2\% live births) and lack of prenatal care (80.8\% live births). Maternal black skin color $(O R=1.9 ; 95 \% C I$ : 1.2-3.2), hemorrhage $(O R=2.2 ; 95 \% C I$ : 1.3-3.9), hypertension $(O R=3.0 ; 95 \% C I: 2.0-4.4)$, syphilis $(O R=3.3$; $95 \% C I$ : 1.5-7.2), lack of prenatal care $(O R=5.6 ; 95 \% C I$ : 2.6-11.7), cesarean section and hospital, were associated with near miss; while hemorrhage $(O R=4.6$; 95\%CI: 1,8-11.3), lack of prenatal care (OR = 17.4; 95\%CI: 6.5-46.8) and hospital, with death. Improvements in access to qualified care for pregnant women and newborns are necessary to reduce neonatal life-threatening conditions.
\end{abstract}

Infant Mortality; Low Birth Weight Infant; Premature Infant; Pregnancy

Complications; Prenatal Care
Pauline Lorena Kale 1

Maria Helena Prado de Mello-Jorge 2

Kátia Silveira da Silva 3

Sandra Costa Fonseca 4

doi: 10.1590/0102-311X00179115

\section{Correspondence}

P. L. Kale

Instituto de Estudos de Saúde Coletiva, Faculdade de Medicina, Universidade Federal do Rio de Janeiro.

Av. Brigadeiro Trompowsky s/n, Praça da Prefeitura Universitária, Rio de Janeiro, RJ 21949-900, Brasil.

pkale@iesc.ufrj.br

1 Instituto de Estudos de Saúde Coletiva, Universidade Federal do Rio de Janeiro, Rio de Janeiro, Brasil.

2 Faculdade de Saúde Pública, Universidade de São Paulo, São Paulo, Brasil.

3 Instituto Nacional de Saúde da Mulher, da Criança e do Adolescente Fernandes Figueira, Fundação Oswaldo Cruz, Rio de Janeiro, Brasil.

4 Instituto de Saúde Coletiva, Universidade Federal Fluminense, Niterói, Brasil. 


\section{Introduction}

Risk factors such as maternal characteristics (low income, low schooling, extreme age group, and hypertensive diseases of pregnancy), newborn characteristics (prematurity, low birth weight, asphyxia, congenital malformation, infection), and obstetric/neonatal care issues are frequently investigated in neonatal mortality studies $1,2,3,4$.

Important predictors of neonatal death have recently been validated as criteria for the definition of neonatal severe morbidity or near miss: a newborn with a life-threatening condition but that survives the neonatal period 5,6,7,8,9. Life-threatening criteria include pragmatic 6 (prematurity, very low birth weight, asphyxia), clinical, laboratory, and case management characteristics. In the continuum of severity, near miss and death are the worst outcomes for newborns 5 .

Relatively little research in Brazil has focused on factors potentially associated with neonatal near miss. According to univariate analysis in a Brazilian study, neonatal near miss showed a positive association with cesarean section and delivery in state capitals or in public hospitals, but was not significantly associated with geographic region, maternal schooling, or social class 9 . In a hospitalbased birth cohort in Uganda, uncomplicated live birth, neonatal near miss, stillbirth, and neonatal deaths differed significantly according to maternal age group and severe obstetric complications 10 . In a multi-country study, cases of near miss based on case management criteria were associated with mode and timing of delivery 11 .

The present study investigated the association between maternal and health care characteristics and life-threatening conditions classified as cases of neonatal near miss or neonatal death among live born infants in six public maternity facilities in São Paulo and Rio de Janeiro States, Brazil, in 2011.

\section{Methodology}

\section{Study design and population}

This was a prospective hospital-based birth cohort study in which the follow-up time was the neonatal period (0-27 days). Potential factors associated with a life-threatening condition were retrospective or concurrent birth exposures obtained from maternity hospitals run by the Brazilian Unified National Health System (SUS) in the cities of São Paulo, São Paulo State, and Niterói and Rio de Janeiro, Rio de Janeiro State, Brazil, for three months in the second semester of 2011. Four of the largest maternity hospitals assisting SUS patients in São Paulo and maternity hospitals with the highest live birth rates in Rio de Janeiro and Niterói were selected. The hospital in Niterói (maternity hospital A) is a referral hospital for low and high-risk pregnancies in Metropolitan Area II of Rio de Janeiro State and the hospital in Rio de Janeiro (maternity hospital B), located in Metropolitan Area I basically assists women from the surrounding area. The selected hospitals in São Paulo were a maternity facility that receives high-risk obstetric and neonatal referrals in Greater São Paulo (maternity hospital C), a university hospital (maternity hospital D), a national referral center for maternal and neonatal health (maternity hospital E), and a charitable maternity service (maternity hospital F).

The selection strategy for newborns during the three months in 2011 (25\% of annual births) was similar to the sampling strategy used in the WHO Global Survey for Monitoring Maternal and Perinatal Health 7 , and was not a random sample. Post-hoc sample size calculation showed $80 \%$ power for detecting neonatal near miss.

This study resulted from the integration of studies on the same subject in the cities of São Paulo, Rio de Janeiro, and Niterói. Primary data collection used interviews with mothers 12 hours postpartum and was conducted by previously trained undergraduate students from health fields. Prenatal care cards, hospital records, and delivery room records were also consulted. Data on birth weight and Apgar score were specifically obtained from hospital records. The interview protocol was the same for all the maternity hospitals in the study.

In-hospital neonatal deaths were investigated by the study team in the three cities. Different strategies were used to detect infant deaths after hospital discharge. In São Paulo, deaths were reported through the Program for Improvement of Mortality Data (PRO-AIM) of the São Paulo municipal govern- 
ment. In Rio de Janeiro and Niterói, the study database was linked to the Mortality Information System (SIM) database of the Rio de Janeiro State Health Department.

Of 7,361 eligible live births in this study, 5,579, 1,224, and 558 occurred, respectively, in the maternity hospitals in São Paulo, Rio de Janeiro, and Niterói. Losses due to missing information for defining life-threatening conditions (birth weight, five-minute Apgar score, or gestational age) corresponded to $0.8 \%$. Exclusion criteria were multiple pregnancy $(2.1 \%)$ and post-neonatal death $(\mathrm{n}=20)$. Additionally, 13 neonatal deaths that did not meet any of the life-threatening criteria were excluded. The study population consisted of 7,126 live born infants (5,299 in São Paulo, 1,157 in Rio de Janeiro, and 518 in Niterói).

\section{Outcomes and covariables}

Life-threatening condition was defined as the presence of at least one pragmatic neonatal near miss criterion: birth weight less than 1,500g, gestational age less than 32 weeks, or five-minute Apgar score of less than seven ${ }^{9}$, validated for this database (sensitivity $=0.72$, specificity $=0.98$, and accuracy $=$ 0.98; gold standard: neonatal death). Newborns without life-threatening conditions and those with life-threatening conditions were compared; the latter were divided into two categories: survivors (near misses) and neonatal deaths. The outcome variable was classified into three categories according to life-threatening condition: live born infants without a life-threatening condition (reference category); live born infants with a life-threatening condition, but who survived (neonatal near miss); and live born infants with a life-threatening condition that died.

The theoretical model for hierarchical determination of severity of newborn condition was based on a model for neonatal death 1 (Figure 1).

Sex of the newborn (male; female) does not comprise any level of hierarchical determination; since it is an important predictor of neonatal mortality, the final model included the newborn's sex, regardless of statistical significance.

\section{Figure 1}

Flowchart for article selection process.

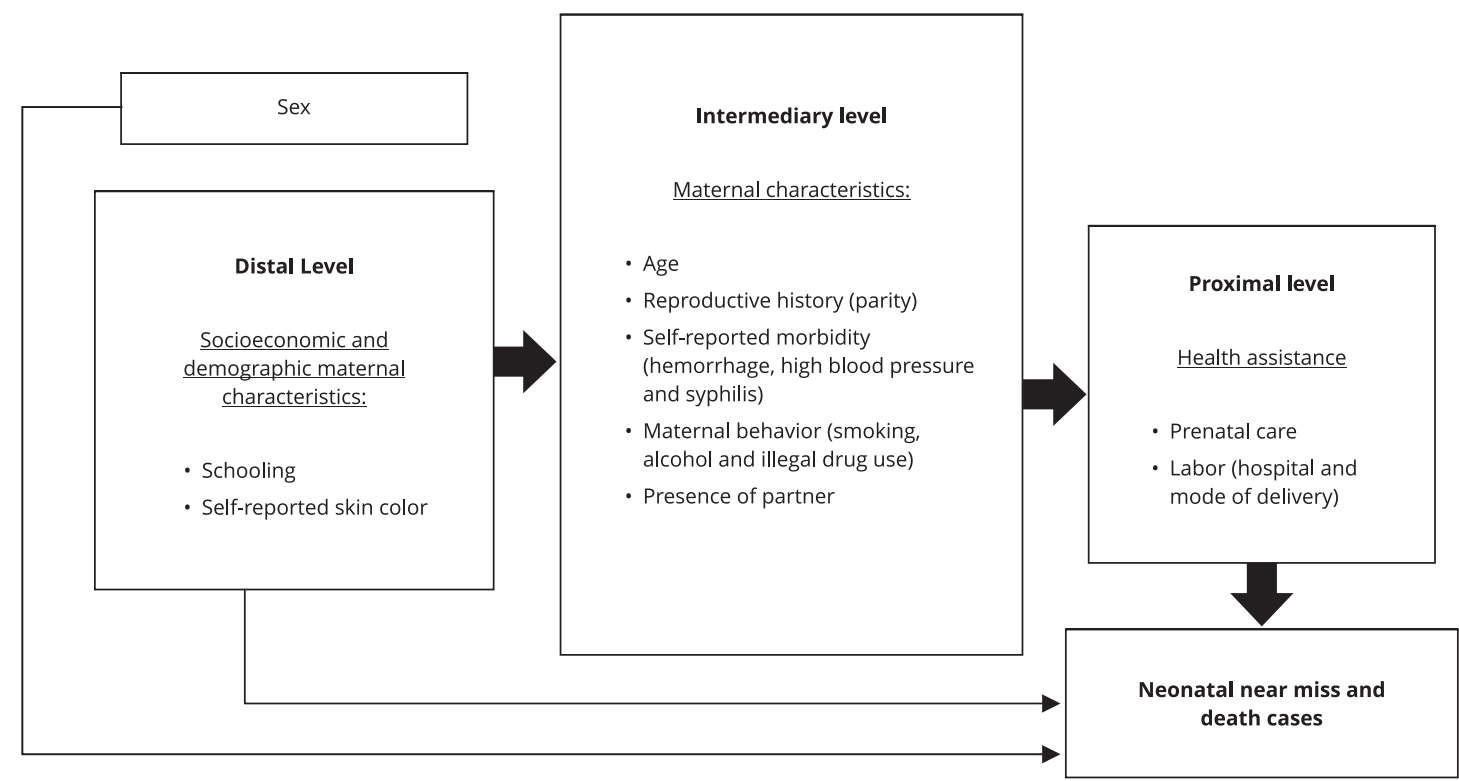

Note: adapted from Lima et al. 1. 
At the distal level, maternal schooling $(<8 ; \geq 8$ years of study) and self-reported skin color (white; brown; black; other) were included. The intermediary level included maternal age group $(<20$; 20-34; $\geq 35$ years), parity (primiparous; multiparous), and the following binary covariables (yes; no): self-reported maternal disease during pregnancy (high blood pressure, hemorrhage, syphilis); risk behavior during pregnancy (smoking; alcohol; drug use), and presence of partner (married; in stable relationship at the time of delivery). The proximal level consisted of healthcare variables: prenatal care ( $\geq 1$ visit: yes; no), maternity hospital of delivery (A; B; C; D; E; F), and mode of delivery (vaginal; cesarean section).

\section{Statistical analyses}

The study described absolute and percentage rates of live births according to severity of condition and independent variables. Near miss and neonatal mortality rates (per 1,000 live births) were estimated according to the same variables. Covariables with $\mathrm{p}$-value $<0.20$ in the univariate analysis were selected for the multivariate model of the respective hierarchical level. Only the variables with p-value $<0.05$ in the multivariate model were kept in the final model. Covariables of the same and previous hierarchical levels were treated as possible confounders 12 . The reference or unexposed category of the covariables was chosen based on the lowest risk. Crude and adjusted odds ratios were calculated with a multinomial regression model. Data were analyzed using SPSS, version 17 (SPSS Inc., Chicago, USA).

\section{Ethical issues}

The study was approved by the Institutional Review Board of the Institute for Studies in Public Health at the Rio de Janeiro Federal University (case number 15/2010), the Rio de Janeiro Municipal Department of Health and Civil Defense (case number 87/2011), research centers at the respective maternity services in Rio de Janeiro State, the Institutional Review Board of the School of Public Health, São Paulo University (case number 2188/11), and participating hospitals in São Paulo. Prior informed consent was signed by all the eligible pregnant women or a parent or guardian in the case of mothers less than 18 years of age.

\section{Results}

Among the 7,126 selected live births, 152 newborns presented life-threatening conditions: 123 (1.7\%) near misses and 29 (0.4\%) neonatal deaths. Prematurity at delivery represented $11.4 \%$ and $1.5 \%$ of the sample (less than 37 and less than 32 weeks gestational age, respectively).

Table 1 shows the distribution of newborns according to demographic, socioeconomic, maternal, gestational, and childbirth characteristics. Neonates of mothers with more schooling ( $\geq 8$ years), brown skin color, ages 20-34 years, and multipara were more prevalent. The proportion of adolescent mothers (<20 years) was high (22\%). High blood pressure during pregnancy was reported by $11.8 \%$ of mothers. Some $14 \%$ of mothers reported smoking and alcohol consumption during pregnancy. Most mothers were married or living with a partner, had received prenatal care, and had vaginal deliveries, although the cesarean rate was high at $32.5 \%$ (Table 1).

Increased risk of neonatal near miss was associated statistically with maternal black skin color (27.8\% live births), maternal age 35 years or older (27.3\%o live births), some disease condition during pregnancy (hemorrhage: $35.2 \%$ live births, high blood pressure: $40.5 \%$ live births; and syphilis: $52.2 \%$ live births), and lack of prenatal care ( $80.8 \%$ live births). The pattern was similar for neonatal mortality, although the rates were lower than for near miss (Table 1).

Primiparous mothers showed higher risk of neonatal near miss but a negative association with neonatal mortality risk. Among risk behavior variables, illegal drug use was associated with increased incidence of near miss (31.9\% live births) and neonatal mortality (21.3\%o live births). Single mothers (unwed or without a partner) showed a nearly fivefold higher risk of near miss compared to neonatal 
Table 1

Absolute and percentage distribution of newborns, neonatal near miss and mortality rates per 1,000 live births according to independent variables by hierarchical level in public maternity hospitals of São Paulo and Rio de Janeiro States, Brazil, 2011.

\begin{tabular}{|c|c|c|c|c|c|c|}
\hline \multirow[t]{2}{*}{ Hierarchical level/Characteristics } & \multicolumn{2}{|c|}{ Live births } & \multicolumn{2}{|c|}{ Near miss rate } & \multicolumn{2}{|c|}{ Mortality rate } \\
\hline & $n$ * & $\%$ & ** & $95 \% \mathrm{Cl}$ & ** & $95 \% \mathrm{Cl}$ \\
\hline \multicolumn{7}{|l|}{ Sex } \\
\hline Male & 3,631 & 51.0 & 17.6 & $13.8-22.4$ & 4.4 & 2.7-7.1 \\
\hline Female & 3,495 & 49.0 & 16.9 & $13.1-21.7$ & 3.7 & $2.2-6.4$ \\
\hline \multicolumn{7}{|l|}{ Distal } \\
\hline \multicolumn{7}{|l|}{ Maternal schooling (years) } \\
\hline$<8$ & 1,362 & 19.7 & 18.4 & $12.5-26.9$ & 2.9 & $1.1-7.5$ \\
\hline$\geq 8$ & 5,559 & 80.3 & 17.3 & $14.2-21.0$ & 4.3 & $2.9-6.4$ \\
\hline \multicolumn{7}{|l|}{ Skin color } \\
\hline White & 2,580 & 37,0 & 14.7 & $10.8-20.2$ & 3.9 & $2.1-7.1$ \\
\hline Brown & 3,272 & 47,0 & 15.9 & $12.1-20.8$ & 3.1 & $1.7-5.6$ \\
\hline Black & 936 & 13.4 & 27.8 & $19.0-40.4$ & 7.5 & 3.6-15.4 \\
\hline Other & 177 & 2.5 & 11.3 & $3.1-40.3$ & 5.6 & $0.1-31.3$ \\
\hline \multicolumn{7}{|l|}{ Intermediary } \\
\hline \multicolumn{7}{|l|}{ Maternal age (years) } \\
\hline$<20$ & 1,593 & 22.4 & 13.8 & $9.1-20.8$ & 3.1 & $1.3-7.3$ \\
\hline $20-34$ & 4,910 & 68.9 & 17.1 & $13.8-21.1$ & 4.3 & $2.8-6.5$ \\
\hline$\geq 35$ & 623 & 8.7 & 27.3 & $17.1-43.3$ & 4.8 & $1.6-14.1$ \\
\hline \multicolumn{7}{|l|}{ Parity } \\
\hline Primiparous & 3,005 & 42.2 & 19.6 & $15.2-25.2$ & 3.3 & $1.8-6.1$ \\
\hline Multiparous & 4,114 & 57.8 & 15.6 & $12.2-19.8$ & 4.6 & $3,0-7.2$ \\
\hline \multicolumn{7}{|l|}{ Hemorrhage } \\
\hline Yes & 398 & 5.6 & 35.2 & $21.1-5.8$ & 15.1 & 6.9-32.5 \\
\hline No & 6,728 & 94.4 & 16.2 & $13.5-19.5$ & 3.4 & 2.3-5.1 \\
\hline \multicolumn{7}{|l|}{ High blood pressure } \\
\hline Yes & 839 & 11.8 & 40.5 & 29.1-56.1 & 8.0 & 3.3-15.5 \\
\hline No & 6,287 & 88.2 & 14.2 & $11.5-17.4$ & 3.7 & $2.4-5.5$ \\
\hline \multicolumn{7}{|l|}{ Syphilis } \\
\hline Yes & 134 & 1.9 & 52.2 & 25.5-103.9 & 14.9 & $4.1-52.8$ \\
\hline No & 6,992 & 98.1 & 16.6 & 13.9-19.9 & 3.9 & $2.7-5.6$ \\
\hline \multicolumn{7}{|l|}{ Smoking } \\
\hline Yes & 1,024 & 14.4 & 21.5 & $14.2-32.3$ & 4.9 & $2.1-1.1$ \\
\hline No & 6,090 & 85.6 & 16.6 & $13.7-20.1$ & 3.9 & $2.7-5.9$ \\
\hline \multicolumn{7}{|l|}{ Alcohol } \\
\hline Yes & 959 & 13.5 & 20.9 & $13.5-32.0$ & 7.3 & $3.5-15.0$ \\
\hline No & 6,156 & 86.5 & 16.7 & $13.8-20.3$ & 3.6 & 2.4-5.4 \\
\hline \multicolumn{7}{|l|}{ Illegal drug use } \\
\hline Yes & 94 & 1.3 & 31.9 & $10.9-89.7$ & 21.3 & $5.8-74.3$ \\
\hline No & 7,021 & 98.7 & 17.1 & $14.3-20.4$ & 3.8 & $2.6-5.6$ \\
\hline \multicolumn{7}{|l|}{ Partner } \\
\hline Yes & 4,603 & 85.3 & 15.0 & 11.9-18.9 & 3.9 & $2.5-6.2$ \\
\hline No & 2,451 & 34.7 & 21.6 & $16.6-28.2$ & 4.5 & $2.5-8,0$ \\
\hline
\end{tabular}

(continues) 
Table 1 (continued)

\begin{tabular}{|c|c|c|c|c|c|c|}
\hline \multirow[t]{2}{*}{ Hierarchical level/Characteristics } & \multicolumn{2}{|c|}{ Live births } & \multicolumn{2}{|c|}{ Near miss rate } & \multicolumn{2}{|c|}{ Mortality rate } \\
\hline & $\mathrm{n}$ * & $\%$ & ** & $95 \% \mathrm{Cl}$ & ** & $95 \% \mathrm{Cl}$ \\
\hline \multicolumn{7}{|l|}{ Proximal } \\
\hline \multicolumn{7}{|l|}{ Prenatal care } \\
\hline Yes & 7,010 & 98.6 & 16.4 & $13.7-19.7$ & 3.3 & $2.2-4.9$ \\
\hline No & 99 & 1.4 & 80.8 & $41.5-151.4$ & 50.5 & $21.8-112.8$ \\
\hline \multicolumn{7}{|l|}{ Maternity/Hospital } \\
\hline A & 543 & 7.6 & 25.8 & $15.4-42.8$ & 20.3 & $11.3-35.9$ \\
\hline B & 1,190 & 16.7 & 26.1 & $18.4-36.7$ & 1.7 & $0.1-6.1$ \\
\hline c & 1,528 & 21.4 & 19.6 & $13.8-27.9$ & 5.2 & $2.7-10.3$ \\
\hline D & 734 & 10.3 & 10.9 & $5.5-21.4$ & 2.7 & $0.1-9.9$ \\
\hline $\mathrm{E}$ & 1,522 & 21.4 & 19.7 & $13.8-28.0$ & 3.3 & $1.4-7.7$ \\
\hline $\mathrm{F}$ & 1,609 & 22.6 & 6.2 & $3.4-11.4$ & 0.6 & $0.1-3.5$ \\
\hline \multicolumn{7}{|l|}{ Mode of delivery } \\
\hline Vaginal & 4,811 & 67.5 & 11.8 & $9.2-15.3$ & 3.7 & $2.4-5.9$ \\
\hline Cesarean & 2,315 & 32.5 & 28.5 & $22.4-36.1$ & 4.8 & $2.7-8.5$ \\
\hline
\end{tabular}

95\%Cl: 95\% confidence interval.

* Total number of live births varies due to frequency of ignored information for each variable;

** Per 1,000 live births.

death. Maternity hospitals A and B in Rio de Janeiro State showed a higher risk of near miss and neonatal mortality compared to those in São Paulo (Table1).

Table 2 shows the univariate analyses by hierarchical levels for neonatal near miss and mortality. The newborn's sex was not associated with the target outcomes $(\mathrm{p} \geq 0.20)$. At the distal level, only maternal black skin color was positively associated with both outcomes. At the intermediary level, except for adolescent motherhood and maternal risk behavior, all the other variables showed statistically significant associations with neonatal near miss. Maternal hemorrhage, high blood pressure, syphilis, and alcohol and illegal drug use showed statistically significant associations with neonatal mortality. At the proximal level, lack of prenatal care, the specific maternity service, and cesarean section were statistically associated with neonatal near miss (except maternity hospital D) and neonatal mortality (except maternity hospitals B and D and cesarean delivery).

Table 3 shows the final multivariate model, adjusted by sex. Neonatal near miss showed a statistically significant association with maternal skin color. Age group $\geq 35$ years, primiparity, hemorrhage, high blood pressure and maternal syphilis maintained a positive association with neonatal near miss, while only hemorrhage was positively associated with neonatal mortality. Finally, lack of prenatal care, maternity hospital (except maternity D), and cesarean delivery were associated with near miss, and only lack of prenatal care and maternity A with neonatal mortality.

\section{Discussion}

The study's results contributed to the understanding of factors associated with life-threatening conditions in neonates, particularly neonatal near miss, for which there is a lack of epidemiological studies. The definition of neonatal near miss is still under discussion and can involve a variety of adverse outcomes and etiologies.

According to the definition used in this study, neonatal near miss and neonatal death cases were limited to newborns with life-threatening conditions. Criteria for definition of life-threatening conditions, namely gestational age less than 32 weeks, birth weight less than 1,500g, or five-minute Apgar score less than seven (pragmatic criteria for definition of near miss 9), correspond to adverse perinatal outcomes and are associated with sociodemographic variables 13, maternal morbidity 14,15,16,17, 
Table 2

Univariate hierarchical analysis of neonatal near miss and death cases in public maternity hospitals in São Paulo and Rio de Janeiro States, Brazil, 2011.

\begin{tabular}{|c|c|c|c|c|c|c|}
\hline \multirow[t]{2}{*}{ Hierarchical level/Associated factors } & \multicolumn{3}{|c|}{ Neonatal near miss } & \multicolumn{3}{|c|}{ Neonatal mortality } \\
\hline & p-value & OR & $95 \% \mathrm{Cl}$ & p-value & OR & $95 \% \mathrm{Cl}$ \\
\hline Male & 0.81 & 1.05 & $0.73-1.49$ & 0.65 & 1.19 & $0.57-2.47$ \\
\hline \multicolumn{7}{|l|}{ Distal } \\
\hline$<8$ years of schooling & 0.79 & 1.06 & $0.68-1.66$ & 0.48 & 0.68 & $0.24-1.96$ \\
\hline Brown skin color & 0.72 & 1.08 & $0.71-1.65$ & 0.60 & 0.79 & $0.33-1.90$ \\
\hline Black skin color & 0.01 & 1.92 & $1.16-3.18$ & 0.17 & 1.96 & $0.74-5.17$ \\
\hline Other skin color/race & 0.72 & 0.77 & $0.18-3.20$ & 0.72 & 1.46 & $0.19-11.43$ \\
\hline \multicolumn{7}{|l|}{ Intermediary } \\
\hline$<20$ years old & 0.37 & 0.80 & $0.50-1.29$ & 0.53 & 0.73 & $0.28-1.94$ \\
\hline$\geq 35$ years old & 0.08 & 1.61 & $0.95-2.73$ & 0.83 & 1.14 & $0.34-3.83$ \\
\hline Primiparous & 0.19 & 1.27 & $0.89-1.81$ & 0.41 & 0.72 & $0.34-1.56$ \\
\hline Hemorrhage & 0.01 & 2.24 & $1.27-3.95$ & 0.00 & 4.55 & $1.84-11.25$ \\
\hline High blood pressure & 0.00 & 2.95 & $1.98-4.41$ & 0.13 & 2.02 & $0.82-4.97$ \\
\hline Maternal syphilis & 0.00 & 3.31 & $1.51-7.23$ & 0.06 & 4.06 & $0.95-17.25$ \\
\hline Smoking & 0.27 & 1.30 & $0.82-2.08$ & 0.66 & 1.25 & $0.47-3.27$ \\
\hline Alcohol & 0.36 & 1.26 & $0.77-2.04$ & 0.10 & 2.06 & $0.88-4.83$ \\
\hline Illegal drug use & 0.27 & 1.93 & $0.60-6.19$ & 0.02 & 5.72 & $1.34-24.43$ \\
\hline Absence of partner & 0.04 & 0.69 & $0.48-0.99$ & 0.71 & 0.86 & $0.41-1.83$ \\
\hline \multicolumn{7}{|l|}{ Proximal } \\
\hline Absence of prenatal care & 0.00 & 5.56 & $2.63-11.74$ & 0.00 & 17.37 & $6.45-46.76$ \\
\hline Maternity hospital A & 0.00 & 4.32 & $1.91-9.78$ & 0.00 & 33.93 & 4.37-263.47 \\
\hline Maternity hospital B & 0.00 & 4.28 & $2.09-8.77$ & 0.41 & 2.76 & $0.25-30.50$ \\
\hline Maternity hospital C & 0.00 & 3.22 & $1.57-6.60$ & 0.04 & 8.58 & $1.07-68.68$ \\
\hline Maternity hospital D & 0.23 & 1.77 & $0.69-4.49$ & 0.23 & 4.41 & $0.40-48.76$ \\
\hline Maternity hospital E & 0.00 & 3.22 & $1.57-6.62$ & 0.13 & 5.37 & $0.63-46.05$ \\
\hline Cesarean section & 0.00 & 2.45 & $1.71-3.50$ & 0.50 & 1.29 & $0.61-2.74$ \\
\hline
\end{tabular}

95\% Cl: 95\% confidence interval; OR: odds ratio.

reproductive history, risk behavior 1,18, and prenatal, delivery, and neonatal care 2,9,19. Our results corroborated previous studies on factors associated with adverse neonatal outcomes.

Black maternal skin color was associated with near miss, although there was no statistical significance for neonatal death. According to Willis et al. 20, color/race determines life trajectories, and adverse birth outcomes can cross generations. Skin color may also reflect discrimination in access to and performance of healthcare 21,22,23.

Advanced maternal age, primiparity, and maternal morbidity were kept in the final multivariate model. Infants born to older mothers showed a nearly twofold risk of neonatal near miss, compared to mothers aged 20 to 34. In the World Health Organization multi-country survey on maternal and newborn health 13, advanced maternal age was also associated with adverse outcomes such as gestational age less than 37 weeks, birth weight less than 2,500g, and five-minute Apgar less than seven. These characteristics are similar, although more sensitive (higher cutoff points for gestational age and birth weight) than those adopted as pragmatic criteria for the definition of near miss in the present study. We did not find an association between advanced maternal age and neonatal mortality, contrary to the results for stillbirth and early neonatal mortality in the WHO study 2.

Primiparity remained as a risk factor for neonatal near miss, even after adjusting for socioeconomic status, maternal age, and maternal morbidity. Primiparity and grand multiparity are consid- 
Table 3

Multivariate hierarchical model of neonatal near miss and deaths cases in public maternity hospitals in São Paulo and Rio de Janeiro States, Brazil, 2011.

\begin{tabular}{|c|c|c|c|c|c|c|}
\hline \multirow[t]{2}{*}{ Hierarchical level/Associated factors } & \multicolumn{3}{|c|}{ Neonatal near miss } & \multicolumn{3}{|c|}{ Neonatal mortality } \\
\hline & p-value & OR & $95 \% \mathrm{Cl}$ & p-value & OR & $95 \% \mathrm{Cl}$ \\
\hline Male & 0.81 & 1.05 & $0.73-1.49$ & 0.65 & 1.19 & $0.57-2.47$ \\
\hline \multicolumn{7}{|l|}{ Distal } \\
\hline Black skin color & 0.01 & 1.92 & $1.16-3.18$ & 0.17 & 1.96 & $0.75-5.17$ \\
\hline \multicolumn{7}{|l|}{ Intermediary } \\
\hline$\geq 35$ years old & 0.04 & 1.76 & $1.01-3.08$ & 0.77 & 1.20 & $0.34-4.20$ \\
\hline Primiparous & 0.01 & 1.74 & $1.16-2.62$ & 0.93 & 0.96 & $0.40-2.28$ \\
\hline Hemorrhage & 0.01 & 2.20 & $1.24-3.91$ & 0.01 & 3.63 & $1.35-9.75$ \\
\hline High blood pressure & 0.00 & 2.63 & $1.73-4.01$ & 0.21 & 1.80 & $0.71-4.55$ \\
\hline Maternal syphilis & 0.01 & 2.90 & $1.30-6.48$ & 0.13 & 3.14 & $0.71-13.82$ \\
\hline \multicolumn{7}{|l|}{ Proximal } \\
\hline Absence of prenatal care & 0.00 & 5.94 & $2.60-13.58$ & 0.00 & 15.26 & $5.12-45.52$ \\
\hline Maternity hospital A & 0.02 & 2.73 & $1.17-6.36$ & 0.00 & 22.85 & 2.79-187.07 \\
\hline Maternity hospital B & 0.01 & 2.86 & $1.36-5.99$ & 0.57 & 2.01 & $0.18-22.93$ \\
\hline Maternity hospital C & 0.01 & 2.83 & $1.36-5.89$ & 0.07 & 7.30 & $0.89-60.28$ \\
\hline Maternity hospital E & 0.01 & 2.66 & $1.27-5.54$ & 0.16 & 4.80 & $0.55-41.81$ \\
\hline Cesarean section & 0.00 & 2.00 & $1.35-2.96$ & 0.91 & 0.91 & $0.39-2.14$ \\
\hline
\end{tabular}

95\% Cl: 95\% confidence interval; OR: odds ratio.

Note: the OR were adjusted for sex variable; co-variables belonged to the same and above hierarchical levels.

ered gestational risk factors 24 ; however, the lack of association with neonatal mortality corroborates the result of a recent nationwide study in Brazil 2.

Regarding hemorrhage and high blood pressure, studies have reported an increased risk of perinatal death 25,26, prematurity, low birth weight, and asphyxia at birth 15 among infants of mothers with hypertension in pregnancy, still a common condition during pregnancy 27,28 , and of mothers with vaginal hemorrhage prior to labor 17,29.

Our study found a high rate of syphilis (1.9\%) when compared to a recent national study in Brazil (1.02\%) 30. Syphilis in pregnancy showed a threefold risk of both near miss and neonatal death in newborns with life-threatening conditions, when compared to those without life-threatening conditions in the final model (the association was statistically significant only for neonatal near miss). According to two meta-analyses, in the absence of appropriate treatment, half of pregnancies in women with syphilis result in adverse perinatal outcomes: abortion, stillbirth, neonatal death, prematurity, low birth weight, and infection 16,31. Despite straightforward diagnosis and treatment, syphilis remains an important public health issue in Brazil.

Some healthcare-related variables remained in the final model. The coverage rate for prenatal care was high in our study (98.6\%), similar to the Brazilian national estimate (98.7\%) 19. Lack of prenatal care thus represented only a small contingent of women and was associated with life-threatening conditions and significantly increased risk of neonatal near miss and death. These outcomes in newborns with life-threatening conditions (for which prematurity is one of the pragmatic criteria) may partly explain the strong association with lack of prenatal care. Although the study did not define adequacy of prenatal care (time of first visit, number of visits, and compliance with prenatal care protocols), which may have weakened the associations, the lack of prenatal care had an important independent effect on neonatal near miss and mortality. According to Viellas et al. 19, several barriers to prenatal care or to early initiation of visits showed social inequalities in Brazil.

Based on odds ratios, the strength of the associations with neonatal near miss was very similar between the maternity hospitals, suggesting that the patient populations treated in the different hospitals had similar background characteristics. 
Cesarean section appeared as a risk factor for neonatal near miss, corroborating the results reported by Silva et al. ${ }^{9}$, and as a protective factor against neonatal mortality, although without reaching statistical significance. Associations between mode of delivery and adverse pregnancy outcome may sometimes be difficult to interpret given the possibility of reverse causality. For example, there is a strong association between maternal morbidity, such as vaginal bleeding and high blood pressure during pregnancy, and cesarean section 32 . Cesarean section may act as a protective factor against adverse pregnancy outcomes, resulting in benefits to mothers and newborns 32,33 . In contrast, cesarean section on demand can be a risk factor for adverse perinatal outcomes like prematurity 34 .

The positive association between specific maternity hospitals and the two outcome variables could be partially explained by patient profile, considering that all the maternity centers except the charitable hospital in São Paulo (the comparison category) treat high-risk pregnancies. However, the university maternity center in São Paulo was not statistically associated with neonatal near miss, and only maternity hospital A (Niterói) was statistically associated with neonatal mortality. A university hospital may offer better obstetric and neonatal care, due to both a qualified staff that follows proven effective protocols and the availability of advance medical technology. Lansky et al. 2 emphasize the implementation of best practices for labor and delivery as a powerful action plan to end preventable neonatal deaths. In the birth cohort study in Pelotas (Rio Grande do Sul State, Brazil), perinatal results were associated with hospital performance (material and human resources, and patient care practices), regardless of the service's user population ${ }^{35}$. Thus, even with a high-risk patient profile, the university hospital presented a higher survival rate in newborns with life-threatening conditions. Conversely, maternity A, also a reference hospital for high-risk pregnancies in Metropolitan Area II, Rio de Janeiro State, showed a high incidence of newborns with life-threatening conditions and the highest neonatal mortality rate, suggesting quality-of-care problems.

In the final model, only hemorrhage in pregnancy, lack of prenatal care, and maternity hospital A were associated with life-threatening conditions, regardless of newborn survival.

Some limitations to the study deserve discussion. First, cohort studies are appropriate for etiological investigations but would be inappropriate for analyzing rare outcomes (neonatal near miss and mortality). The study chose public maternity hospitals with higher numbers of births, similar to the sampling strategy used in the WHO Global Study on Maternal and Perinatal Health 7, but it was not a random sample. Additionally, maternal diseases in pregnancy may have been misclassified, since they were self-reported. According to Assarag et al. 36, self-reported maternal morbidity tends to be more specific than sensitive and can be influenced by maternal age and schooling. If this were true in the present study, more false-negatives would be expected. Nonetheless, the study showed strong associations between the target outcomes and hypertension and vaginal hemorrhage, in agreement with the national and international literature.

Some of the study's methodological advantages deserve highlighting. Since the near miss concept is still new and under debate, the study makes a relevant contribution by emphasizing the definition of neonatal near miss based on pragmatic criteria (gestational age, birth weight, and five-minute Apgar score), with two positive characteristics: widespread availability of data and a user-friendly approach, favoring both clinical and epidemiological use ${ }^{6}$. As for analytical advantages, the hierarchical modeling strategy avoids weakening the associations with social (distal) determinants when incorporating more proximal determinants into the model. The theoretical model based on the literature facilitated the use of this analytical strategy and the interpretation of statistical associations. Multinomial regression allowed a more feasible interpretation of the associations since the regression coefficient was the odds ratio, frequently used by epidemiological studies to measure association. Additionally, the effects of regressors were adjusted for the same covariables for both target outcomes, allowing for a direct comparison of results.

Reduction of neonatal mortality in Brazil represents an important achievement for maternal and child health, but the prevention of perinatal life-threatening conditions is still a major challenge. Most newborns with life-threatening conditions survived the neonatal period, but they will likely require greater attention from health services and families due to the chronic character of some of their conditions, thus contributing to a new childhood morbidity profile 37 . 


\section{Contributors}

P. L. Kale, M. H. P. Mello-Jorge, K. S. Silva and S. C. Fonseca conceived the study design, participated in the study planning and supervised the field work team, contributed to the analysis of the manuscript results and read, gave suggestions to and approved the final manuscript.

\section{Acknowledgments}

We are grateful to: the Executive Board and the Study Center of the maternity hospitals; the College of Public Health - USP (FAPESP-PPSUS 2009); the research coordinator, Professor Ruy Laurenti; the Fernandes Figueira National Institute of Women's, Children's and Adolescent's Health, Fiocruz (CNPq-20/2010), Institute for Studies in Public Health IESC-UFRJ (scholarships - PET Saúde/ Ministry of Health, 7/2010 and FAPERJ scientific initiation scholarships); and the Institute of Community Health - ISC-UFF (scientific initiation scholarships).

\section{References}

1. Lima S, Carvalho ML, Vasconcelos AGG. Proposta de modelo hierarquizado aplicado à investigação de fatores de risco de óbito infantil neonatal. Cad Saúde Pública 2008; 24:1910-6.

2. Lansky S, Friche AAL, Silva AAM, Campos D, Bittencourt SDA, Carvalho ML, et al. Pesquisa Nascer no Brasil : perfil da mortalidade neonatal e avaliação da assistência à gestante e ao recém-nascido. Cad Saúde Pública 2014; 30 Suppl:S192-207.

3. Lawn JE, Blencowe H, Oza S, You D, Lee ACC, Waiswa P, et al. Every newborn: progress, priorities, and potential beyond survival. Lancet 2014; 384:189-205.

4. Marshall G, Tapia J, D’Apremont I, Grandi C, Barros C, Alegria A, et al. A new score for predicting neonatal very low birth weight mortality risk in the NEOCOSUR South American Network. J Perinatol 2005; 25:577-82.

5. Avenant T. Neonatal near miss: a measure of the quality of obstetric care. Best Pract Res Clin Obstet Gynaecol 2009; 23:369-74.

6. Pileggi C, Souza JP, Cecatti JG, Faúndes A. Neonatal near miss approach in the 2005 WHO Global Survey Brazil. J Pediatr (Rio J.) 2010; 86:21-6.

7. Souza J, Gülmezoglu A, Carroli G, Lumbiganon P, Qureshi Z. The World Health Organization multicountry survey on maternal and newborn health: study protocol. BMC Health Serv Res 2011; 11:286.

8. Pileggi-Castro C, Camelo JS, Perdoná GC, Mussi-Pinhata MM, Cecatti JG, Mori R, et al. Development of criteria for identifying neonatal near-miss cases: analysis of two WHO multicountry cross-sectional studies. BJOG 2014; 121 Suppl 1:110-8.

9. Silva AAM, Leite AJM, Lamy ZC, Moreira MEL, Gurgel RQ, Cunha AJLA, et al. Morbidade neonatal near miss na pesquisa Nascer no Brasil Neonatal near miss in the Birth in Brazil survey. Cad Saúde Pública 2014; 30 Suppl:S182-91.

10. Nakimuli A, Mbalinda SN, Nabirye RC, Kakaire O, Nakubulwa S, Osinde MO, et al. Still births, neonatal deaths and neonatal near miss cases attributable to severe obstetric complications: a prospective cohort study in two referral hospitals in Uganda. BMC Pediatr 2015; 15:44.

11. Ganchimeg T, Morisaki N, Vogel JP, Cecatti JG, Barrett J, Jayaratne K, et al. Mode and timing of twin delivery and perinatal outcomes in low- and middle-income countries: a secondary analysis of the WHO Multicountry Survey on Maternal and Newborn Health. BJOG 2014; 121 Suppl:89-100.

12. Kleibaum DG. Statistics in the health sciences. Logistic regression: a self-learning text. New York: Spinger-Velag; 1994. 
13. Laopaiboon M, Lumbiganon P, Intarut N, Mori R, Ganchimeg T, Vogel JP, et al. Advanced maternal age and pregnancy outcomes: a multicountry assessment. BJOG 2014; 121 Suppl:49-56.

14. Seyom E, Abera M, Tesfaye M, Fentahun N. Maternal and fetal outcome of pregnancy related hypertension in Mettu Karl Referral Hospital, Ethiopia. J Ovarian Res 2015; 8:4-10.

15. Abalos E, Cuesta C, Carroli G, Qureshi Z, Widmer M, Vogel JP, et al. Pre-eclampsia, eclampsia and adverse maternal and perinatal outcomes: a secondary analysis of the World Health Organization Multicountry Survey on Maternal and Newborn Health. BJOG 2014; 121Suppl:14-24.

16. Qin J, Yang T, Xiao S, Tan H, Feng T, Fu H. Reported estimates of adverse pregnancy outcomes among women with and without syphilis: a systematic review and meta-analysis. PLoS One 2014; 9:e102203.

17. Adane AA, Ayele TA, Ararsa LG, Bitew BD. Adverse birth outcomes among deliveries at Gondar University Hospital, Northwest Ethiopia. BMC Pregnancy Childbirth 2014; 14:90.

18. Levy D, Jiang M, Szklo A, Almeida LM, Autran M, Bloch M. Smoking and adverse maternal and child health outcomes in Brazil. Nicotine Tob Res 2013; 15:1797-804.

19. Viellas EF, Domingues RMSM, Dias MAB, Gana SGN, Theme Filha MM, Costa JV. Assistência pré-natal no Brasil. Cad Saúde Pública 2014; 30 Suppl:S85-100.

20. Willis E, McManus P, Magallanes N, Johnson $\mathrm{S}$, Majnik A. Conquering racial disparities in perinatal outcomes. Clin Perinatol 2014; 41:847-75.

21. Bairros FS, Meneghel SN, Costa JSD, Bassani DG, Menezes AMB, Gigante DP, et al. Desigualdades raciais no acesso à saúde da mulher no Sul do Brasil. Cad Saúde Pública 2011; 27:2364-72.

22. Domingues RMSM, Leal MDC, Hartz ZMA, Dias MAB, Vettore MV. Acesso e utilização de serviços de pré-natal na rede SUS do município do Rio de Janeiro, Brasil. Rev Bras Epidemiol 2013; 16:953-65.

23. Fonseca SC, Kale PL, Silva KS. Pré-natal em mulheres usuárias do Sistema Único de Saúde em duas maternidades no Estado do Rio de Janeiro, Brasil: a cor importa? Rev Bras Saúde Matern Infant 2015; 15:209-17.

24. Ministério da Saúde. Programa de Humanização do Pré-natal e Nascimento. Brasília: Ministério da Saúde; 2000.

25. Endeshaw G, Berhan Y. Perinatal outcome in women with hypertensive disorders of pregnancy: a retrospective cohort study. Int Sch Res Notices 2015; 2015:208043.
26. Barbosa IRC, Silva WBM, Cerqueira GSG, Novo NF, Almeida FA, Novo JLVG. Maternal and fetal outcome in women with hypertensive disorders of pregnancy: the impact of prenatal care. Ther Adv Cardiovasc Dis 2015; 9:140-6.

27. Foo L, Tay J, Lees CC, McEniery CM, Wilkinson IB. Hypertension in pregnancy: natural history and treatment options. Curr Hypertens Rep 2015; 17:1-18.

28. Amaral E, Souza JP, Surita F, Luz AG, Sousa $\mathrm{MH}$, Cecatti JG, et al. A population-based surveillance study on severe acute maternal morbidity (near-miss) and adverse perinatal outcomes in Campinas, Brazil: The Vigimoma Project. BMC Pregnancy Childbirth 2011; 11:9.

29. Iyoke CA, Lawani LO, Ezugwu EC, Ilo KK, Ilechukwu GC, Asinobi IN. Maternal risk factors for singleton preterm births and survival at the University of Nigeria Teaching Hospital, Enugu, Nigeria. Niger J Clin Pract 2015; 18:744-50.

30. Domingues RMSM, Szwarcwald CL, Souza Junior PRB, Leal MC. Prevalência de sífilis na gestação e testagem pré-natal: estudo Nascer no Brasil. Rev Saúde Pública 2014; 48:766-74.

31. Newman L, Kamb M, Hawkes S, Gomez G, Say L, Seuc A, et al. Global estimates of syphilis in pregnancy and associated adverse outcomes: analysis of multinational antenatal surveillance data. PLoS Med 2013; 10:e1001396.

32. Pádua KS, Osis MJD, Faúndes A, Barbosa AH, Moraes Filho OB. Fatores associados à realização de cesariana em hospitais brasileiros. Rev Saúde Pública 2010; 44:70-9.

33. Souza JP, Pileggi-Castro C. Sobre o parto e o nascer: a importância da prevenção quaternária. Cad Saúde Pública 2014; 30 Suppl:11-3.

34. Bettiol H, Rona R, Chinn S, Goldani M, Barbieri M. Factors associated with preterm births in southeast Brazil. Paediatr Perinat Epidemiol 2000; $14: 30-8$.

35. Barros AJ, Matijasevich A, Albernaz EP, Victora CG. Mortalidade neonatal: descrição e efeito do hospital de nascimento após ajuste de risco. Rev Saúde Pública 2008; 42:1-9.

36. Assarag B, Dubourg D, Maaroufi A, Dujardin B, De Brouwere V. Maternal postpartum morbidity in Marrakech: what women feel what doctors diagnose? BMC Pregnancy Childbirth 2013; 13:225.

37. Moreira, MEL, Goldani MZ. A criança é o pai do homem: novos desafios para a área de saúde da criança. Ciênc Saúde Coletiva 2010; 15:321-7. 


\section{Resumo}

Objetivou-se avaliar os fatores associados a casos de near miss neonatal e óbitos neonatais em seis maternidades públicas nos Estados de São Paulo e Rio de Janeiro, Brasil, em 2011. Os desfechos foram investigados através de um estudo prospectivo de coorte de nascimentos com base hospitalar, entre nascidos vivos com ameaça à vida. As associações foram testadas através de modelos de regressão logística multivariada com níveis hierárquicos. Foram observadas altas taxas de near miss para sífilis materna (52,2\%o nascidos vivos) e falta de atendimento pré-natal (80,8\% nascidos vivos). Cor materna preta $(O R=1,9$; IC95\%; $1,2-$ 3,2), hemorragia $(O R=2,2$; IC95\%: 1,3-3,9), hipertensão (OR = 3,0; IC95\%: 2,0-4,4), sífilis $(O R=3,3$; IC95\%: 1,5-7,2), falta de pré-natal $(O R=5,6$; IC95\%: 2,6-11,7), cesariana e hospital específico estiveram associados ao near miss. Enquanto isso, hemorragia (OR $=4,6$; IC95\%: 1,8-11,3), falta de pré-natal (OR = 17,4; IC95\%: 6,5-46,8) e hospital especifico estiveram associados ao óbito neonatal. São necessárias melhoras no acesso ao atendimento qualificado para gestantes e recém-nascidos para reduzir os riscos à vida dos neonatos.

Mortalidade Infantil; Recém-Nascido de Baixo Peso; Prematuro; Complicações na Gravidez; Cuidado Pré-Natal

\section{Resumen}

El objetivo fue evaluar los factores asociados a casos de near miss neonatal y óbitos neonatales en seis maternidades públicas en los estados de São Paulo y Río de Janeiro, Brasil, en 2011. Los desenlaces se investigaron a través de un estudio prospectivo de cohorte de nacimientos con base hospitalaria, entre nacidos vivos con condiciones que involucraron riesgo de muerte. Las asociaciones fueron probadas a través de modelos de regresión logística multivariada con niveles jerárquicos. Se observaron altas tasas de near miss para sifilis materna (52,2\%o nacidos vivos) y falta de atención pre-natal (80,8\% nacidos vivos). Etnia materna negra $(O R=1,9$; IC95\%; 1,2-3,2), hemorragia $(O R=2,2 ;$ IC95\%:1,3-3,9), hipertensión $(O R=3,0 ;$ IC95\%: 2,0-4,4), sifilis $(O R=3,3$; IC95\%: 1,5-7,2), falta de pre-natal $(O R=5,6$; IC95\%: 2,6-11,7), cesárea y hospital específico estuvieron asociados a la morbilidad near miss. Mientras tanto, hemorragia $(O R=4,6$; IC95\%: 1,8-11,3), falta de pre-natal (OR = 17,4; IC95\%: 6,5-46,8) y hospital específico estuvieron asociados al óbito neonatal. Se necesitan mejoras en el acceso a la atención cualificada para gestantes y reciénnacidos, con el fin de reducir los riesgos a la vida de los neonatos.

Mortalidad Infantil; Recién Nacido de Bajo Peso; Prematuro; Complicaciones del Embarazo; Atención Prenatal
Submitted on 26/Nov/2015

Final version resubmitted on 05/Jun/2016

Approved on 16/Jun/2016 